\title{
A study of nutrient and cost analysis of gluten-free packaged products from Turkey
}

\section{Türkiye'de paketli glutensiz ürünlerin besin ögesi ve fiyat analizleri üzerine bir çalıșma}

\author{
Mahmut BODUR ${ }^{1}$ (ID), Esra TUNÇER ${ }^{1}$ (ID), Alev KESER ${ }^{1}$ (ID)
}

\section{ABSTRACT}

Objective: Gluten-free products, despite their increasing popularity, energy and macronutrient contents are unknown. Therefore, this study aims to compare gluten-free products with their gluten containing counterparts on energy, macronutrients (carbohydrate, added sugar, total fat, saturated fat, dietary fiber, protein) and prices.

Methods: In this study, 129 gluten-free (GF) and 304 similar gluten-containing (GC) products are bought from five hypermarkets in which located in Ankara, the capital city of Turkey to analyze their contents of energy, macronutrients, and prices based on their label information. The products were evaluated in eight subgroups: bread, pasta, flour, breakfast cereals, processed meat products, snack bars, sweet biscuitscookies-cakes, crackers-salty crispies. The comparisons between groups performed using SPSS software.

Results: In this study, gluten-free foods in bread, pasta, flour, biscuits-cookies-cakes, and crackerssalty crispies products are found to contain less protein than gluten containing products $(p<0.05)$. Besides, compared to their GC counterparts, GF bread contains more total fat, and GF flours contain more carbohydrates $(p<0.05)$. GF pasta contains less fiber and more carbohydrate than $\mathrm{GC}$ equivalents $(p<0.05)$.

\section{ÖZET}

Amaç: Artan popülerliklerine rağmen, glutensiz ürünlerin enerji ve makro besin ögesi içerikleri tam olarak bilinmemektedir. Bu nedenle, bu çalșşmada enerji içeriği, makro besin ögesi içerikleri (karbonhidrat, eklenmiş şeker, toplam yağ, doymuș yağ, posa, protein) ve fiyat açısından glutensiz ürünlerin gluten içeren muadilleriyle kıyaslanması amaçlanmıştır.

Yöntem: Bu çalıșmada, enerji içeriği, makro besin ögesi içerikleri ve fiyat bilgisini etiket bilgilerine göre değerlendirmek için 129 glutensiz ürün ve 304 gluten içeren ürün Türkiye'nin bașkenti olan Ankara'da bulunan beș hipermarketten satın alınmıștır. Ürünler; ekmek, makarna, un, kahvaltılık gevrekler, işlenmiş et ürünleri, atıştırmalık barlar, tatlı bisküvi - kurabiye - kekler, krakerler - tuzlu gevrekler olmak üzere sekiz alt grupta değerlendirilmiştir. Gruplar arasındaki karşılaștırmalar SPSS yazılımı kullanılarak gerçekleștirilmiştir.

Bulgular: Bu çalıșmada ekmek, makarna, un, bisküvi - kurabiye - kek ve kraker - tuzlu atıștırmalık gruplarında yer alan glutensiz ürünlerin gluten içeren muadillerine göre daha az protein içerdiği bulunmuştur $(p<0.05)$. Ayrıca, gluten içeren muadillerine göre glutensiz ekmek daha fazla toplam yağ içerirken; glutensiz unlar ise daha fazla karbonhidrat içermektedir $(p<0.05)$. Glutensiz makarnalar, gluten içeren muadillerine kıyasla daha az

${ }^{1}$ Ankara University, Faculty of Health Sciences, Department of Nutrition and Dietetics, Ankara

İletişim / Corresponding Author : Mahmut BODUR

Tepebaşı Mahallesi Fatih Caddesi No: 197/A PK: 06290 Keçiören / Ankara - Türkiye

E-posta / E-mail : mahmutbodur@ankara.edu.tr

DOI ID : 10.5505/TurkHijyen.2021.97344

Bodur M, Tunçer E, Keser A.A study of nutrient and cost analysis of gluten-free packaged products from Turkey.

Turk Hij Den Biyol Derg, 2021; 78(3): 333 - 342 
Gluten-free sweet biscuits-cookies-cakes group has more added sugar than gluten-containing counterparts $(p<0.05)$. Gluten-free snack products were found to contain more total fat, less fiber than counterparts. The gluten-free product groups except for processed meat products were more expensive than glutencontaining product groups $(p<0.001)$.

Conclusion: Despite the variations of food groups, gluten-free products are not nutritionally superior for healthy people because of their high carbohydrate, high total fat, low protein, and low dietary fiber contents. In addition, the high prices of GF products should also be considered. As a conclusion that recommending glutenfree products to healthy individuals will not provide additional benefits.

Key Words: Gluten-free product, cost, food label, healthy eating posa ve daha fazla karbonhidrat içermektedir $(p<0.05)$. Glutensiz bisküvi-kurabiye-kekler, gluten içeren muadillerine göre daha fazla șeker içermektedir $(p<0.05)$. Glutensiz atıștırmalık ürünlerinin, muadillerine göre daha çok toplam yağ ve daha az posa içerdiği bulunmuștur. İșlenmiș et ürünleri dıșındaki glutensiz ürün gruplarının tamamı, gluten içeren ürün gruplarından daha pahalıdır $(p<0.001)$.

Sonuç: Besin gruplarının çeșitliliğine rağmen, glutensiz ürünler, yüksek karbonhidrat, yüksek toplam yağ, düșük protein, ve düșük diyet lifi içerikleri nedeniyle sağııkı bireyler için beslenme açısından üstün değildirler. Ayrıca, glutensiz ürünlerin yüksek fiyatları da göz önünde bulundurulmalıdır. Sonuç olarak, sağlıklı bireylere glutensiz ürünleri önermek ek bir fayda sağlamayacaktır.

Anahtar Kelimeler: Glutensiz ürünler, fiyat, besin etiketi, sağlıklı beslenme

\section{INTRODUCTION}

Today, due to changing dietary habits, the content of a balanced and adequate nutrition concept is being questioned (1). There is increasing information pollution about what is healthy and what is not healthy. The gluten-free diet is also one of them. The gluten-free (GF) diet is increasing in popularity in the general population. As a result, sales of glutenfree products are increasing. Global sales of GF foods increased by $12.6 \%$ in 2016 . This may be due to increased awareness of gluten-related diseases and changing consumer perception that gluten-free products are healthier (2).

The gluten-free diet is the elimination of all gluten and gluten-containing products from the diet. Although the most abundant dietary sources of gluten appear to be barley, wheat, rye, and oats, many food additives, medicines, and cosmetics also contain some gluten (3). Gluten-free diet is the gold standard treatment for some diseases such as celiac disease, wheat allergy, nonceliac gluten sensitivity $(4,5)$. Exposure to gluten in patients with celiac may cause gastrointestinal symptoms. Nevertheless, gluten-free diet is not recommended for the general population, and there is no evidence that the glutenfree diet is beneficial except for celiac disease and gluten-related disorders (6). According to a study, the gluten-free diet did not provide additional benefits for the health of individuals who are under no compulsion to adhere to a gluten-free diet (7). Additionally, the gluten-free diet may have some risks like nutrient deficits, constipation, missed diagnosis of celiac disease (5). Routine initiation of a glutenfree diet may hide a diagnosis of celiac disease. It is important to note that patients should be on a gluten-containing diet at diagnostic testing due to avoid false-negative results in tests used in celiac 
disease diagnosis (8). Inadequacies of micronutrients such as zinc, magnesium, iron, calcium, vitamin $D$, thiamine, pyridoxine, folate, and vitamin $B_{12}$ may be common in a gluten-free diet $(9,10)$. Besides, insufficient dietary fiber intake on a gluten-free diet causes to constipation (9). Other possible harms of the gluten-free diet are increased financial costs, and social impairment/restrictions (11). However, on the other hand, there are not enough studies on the longterm effects of gluten-free diet.

Gluten-free products have a wide range of products in recent years. Increasing numbers of gluten-free products also attract consumers' interest (3). The gluten-free diet is thought to be healthy because of avoiding processed foods and also increasing consumption of other whole grains (pseudo-cereals), low-energy density vegetables (12). On the other hand, gluten-free diet may be deficient in cereals and fiber, may have high in fat content, and may lead to lack of vitamins and minerals (5, 9). The availability of gluten-free products has been partially increased, but gluten-free products are more expensive than gluten-containing counterparts $(13,14)$. Also, it is indicated that consumers have the perception that gluten-free products are healthier than conventional counterparts (15). However, the energy and macronutrient content of the gluten-free products that considered healthier is also a question mark against gluten-containing products.

Therefore, the aim of this study is to compare gluten-free products with their glutencontaining counterparts on energy, macronutrients (carbohydrate, added sugar, total fat, saturated fat, dietary fiber, protein) and prices on label information.

\section{MATERIAL and METHOD}

\section{Design and Data}

This study consists of comparing gluten-free versus gluten-containing foods based on their labels. The data were obtained from the hypermarkets with the highest product diversity, located in the central places from given in another study conducted by the researchers (16). Briefly, between January and May 2018, 129 gluten-free products and 304 its similar gluten-containing products are taken from five hypermarkets in Ankara to analyzed their contents of energy and carbohydrate/ protein/ total fat/ saturated fat/ fiber based on their label information. Price comparisons of products are calculated on the price paid for $100 \mathrm{~g}$ of each product (Figure 1). Each product symbolized the table in " $n$ ". Number of brands and products included in this study is given in Table 1.

\section{Food categories included}

Products are classified as gluten-free or glutencontaining if a declaration appeared on their packages. In the study, the main food groups, bread, flour, pasta, breakfast cereals, processed meat products (sausage, sucuk, salami, smoked meat, jambon, canned mackerel) which are food groups with a high contribution to the energy content of the gluten-free diet, were included. Also, several snack product groups, including wafers, sweet biscuits, cookies, cakes, chocolate-filled biscuits, snack bars, crackers, salty crispies, mainly produced for the gluten-free diet, were included in this study.

There is no enrichment procedure developed for gluten-free products in Turkey. Therefore, vitaminmineral contents of the products were not included in the comparison. In addition, most labels of products do not exist vitamin and mineral information. In order to determine the accessibility of the packaged products included in the study, the products offered for sale at each period were included, given the seasonal effects. The product that has been discounted for any reason is not included in the study.

\section{Statistical analyses}

Statistical analyses were performed in SPSS software. The variables were investigated using visual and analytical methods to determine whether 
Tablo 1. Number of brands and products

\begin{tabular}{|c|c|c|c|c|c|c|}
\hline \multirow[t]{2}{*}{ Food Categories } & \multicolumn{2}{|c|}{ Gluten-Free } & \multicolumn{2}{|c|}{ Gluten-Containing } & \multicolumn{2}{|c|}{ Total } \\
\hline & Brands & Products $(n)$ & Brands & Products $(n)$ & Brands & Products $(n)$ \\
\hline Bread & 4 & 13 & 8 & 32 & 12 & 45 \\
\hline Pasta & 8 & 24 & 16 & 76 & 24 & 100 \\
\hline Flour & 7 & 21 & 12 & 34 & 19 & 55 \\
\hline Breakfast Cereals & 3 & 6 & 4 & 17 & 7 & 23 \\
\hline Processed Meat Products & 2 & 13 & 14 & 31 & 16 & 44 \\
\hline Snack Bars & 5 & 12 & 8 & 26 & 13 & 38 \\
\hline Sweet Biscuits - Cookies-Cakes & 6 & 28 & 20 & 65 & 26 & 93 \\
\hline Crackers - Salty Crispies & 6 & 12 & 7 & 23 & 13 & 35 \\
\hline
\end{tabular}

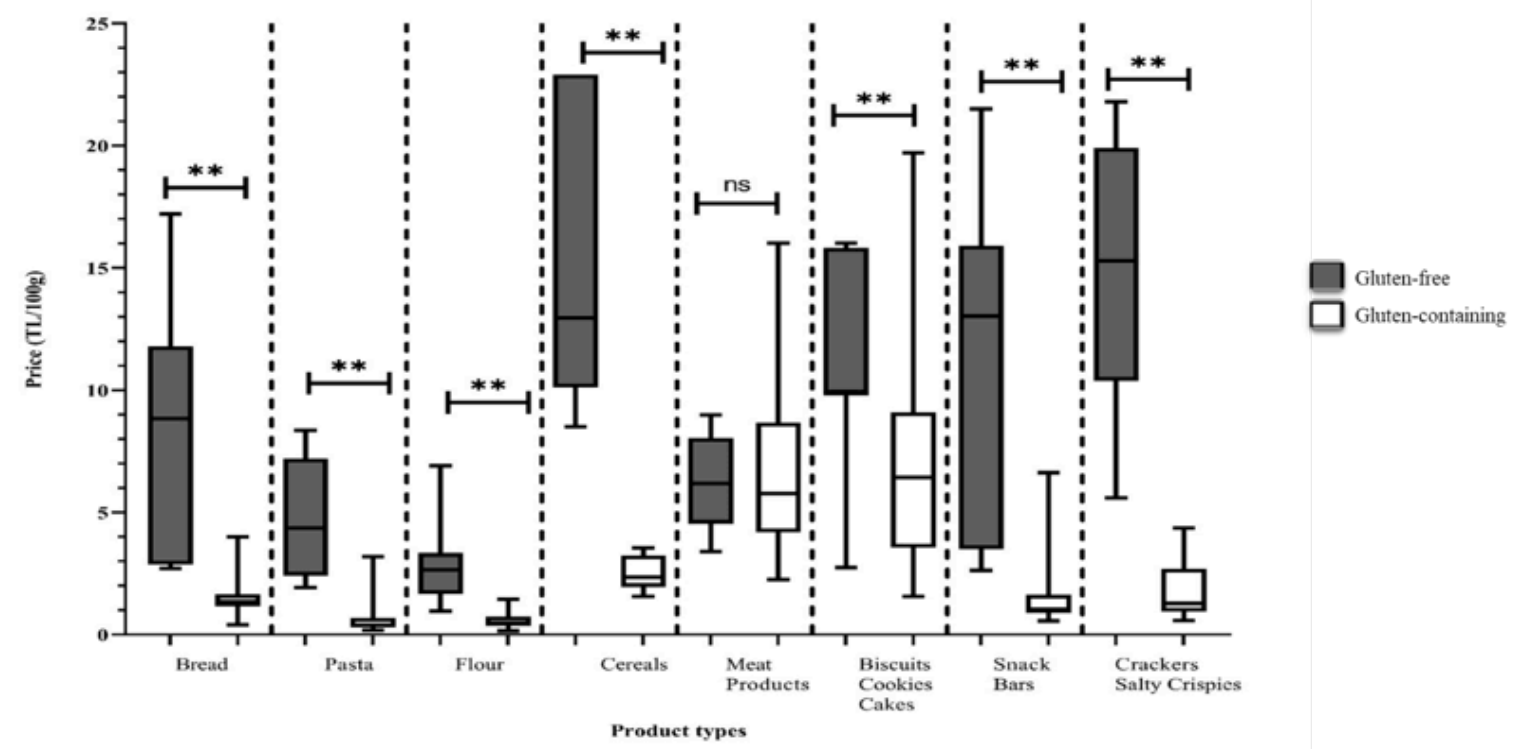

Figure 1. The price comparison of the groups based on gluten status ("TL/per $100 \mathrm{~g}$ "). Mann-Whitney U was conducted. ${ }^{*} p<0.05 ;{ }^{* *} p<0.001$

they are normally distributed. Descriptive analyses were presented using medians and interquartile ranges (IQR) for non-normally distributed variables. The Mann-Whitney $U$ test was used to compare parameters between gluten-free products and their gluten-containing counterparts. In all analyses, a 5\% significance level $(p<0.05)$ was considered. 


\section{RESULTS}

In this cross-sectional market study, a total of 433 products, 129 gluten-free products, and 304 glutenequivalent products were included. Table 2 shows the comparison of energy and macronutrients according to the gluten content of the products in the main food groups. In the bread group, the median value of total fat content of gluten-containing breads was $1.98 \mathrm{~g}$, whereas the median value of gluten-free products was $4.75 \mathrm{~g}(p<0.05)$. In terms of protein content, the median value was $10.4 \mathrm{~g}$ in glutencontaining products, whereas it was $3.70 \mathrm{~g}$ in glutenfree products $(p<0.001)$. There was no statistical significance difference between the bread groups in terms of energy, carbohydrates, added sugar, saturated fat, and dietary fiber $(p>0.05)$.

In the pasta group, the carbohydrate content of the gluten-free products was $78.00 \mathrm{~g}$, while the gluten-containing products were $73.10 \mathrm{~g}(p<0.001)$. The protein content median value of gluten-free products was $6.65 \mathrm{~g}$; it was $10.70 \mathrm{~g}$ for glutencontaining products $(p<0.001)$. When the dietary fiber contents were examined, the median was $1.20 \mathrm{~g}$ for gluten-free products and $3.00 \mathrm{~g}$ for gluten-containing products $(p<0.001)$. No statistically significant difference was found in terms of energy, added sugar, total fat, and saturated fat in pasta groups $(p>0.05)$.

In the flour group, the carbohydrate median value of gluten-free products was $77.00 \mathrm{~g}$, whereas, for gluten-containing products, this value was $73.00 \mathrm{~g}$ $(p<0.001)$. In terms of protein contents, the median value of gluten-free products was $3.70 \mathrm{~g}$, whereas it was $12.30 \mathrm{~g}$ in gluten-containing products $(p<0.001)$. There was no statistically significant difference in terms of energy, added sugar, total fat, saturated fat, dietary fiber in flour group products $(p>0.05)$.

In the breakfast cereals group, the median added sugar content of gluten-free products was $4.10 \mathrm{~g}$ and $19.50 \mathrm{~g}$ in gluten-containing products $(p<0.001)$. There was no statistically significant difference in terms of energy, carbohydrate, total fat, saturated fat, protein, and dietary fiber in the breakfast cereal groups ( $p>0.05)$.

Processed meat products have been introduced as gluten-free in recent years. When the total carbohydrate amounts were examined, the median value of gluten-free products was $3.00 \mathrm{~g}$, while it was found to be $1.57 \mathrm{~g}$ in gluten-containing products $(p<0.001)$. There was no statistically significant difference in processed meat products in terms of energy, total fat, and protein values $(p>0.05)$.

Energy, carbohydrate, added sugar, total fat, saturated fat, protein, and dietary fiber values in $100 \mathrm{~g}$ according to the label information of different snack groups are shown in Table 2. In the snack bars groups, the median amount of carbohydrate in gluten-free products was $53.05 \mathrm{~g}$, while it was 56.65 $g$ in gluten-containing products $(p<0.05)$. When the total fat amount was examined, the median value of gluten-free products was $28.70 \mathrm{~g}$, while it was 21.60 $\mathrm{g}$ for gluten-containing products $(p<0.05)$. When the dietary fiber was examined, the median of glutenfree products was $4.10 \mathrm{~g}$, whereas it was $5.05 \mathrm{~g}$ for gluten-containing products $(p<0.05)$. No statistically significant difference was found in energy, added sugar, saturated fat, and protein amounts in snack bars groups $(p>0.05)$.

Sweet biscuits-cookies-cakes group in terms of carbohydrate amounts of gluten-free products with a median value of $67.50 \mathrm{~g}$, while $62.40 \mathrm{~g}$ glutencontaining products $(p<0.05)$. When the added sugar amount was examined, it was found that while gluten-free products were $29.20 \mathrm{~g}$, it was $24.50 \mathrm{~g}$ in gluten-containing products $(p<0.05)$. The amount of protein was $4.75 \mathrm{~g}$ in gluten-free products and 6.40 $\mathrm{g}$ in gluten-containing products $(p<0.001)$. There was no statistically significant difference in the amount of energy, total fat, saturated fat, and dietary fiber in the packaged biscuit-cookie-cake group products $(p>0.05)$.

In the crackers-salty crispies group, the median 


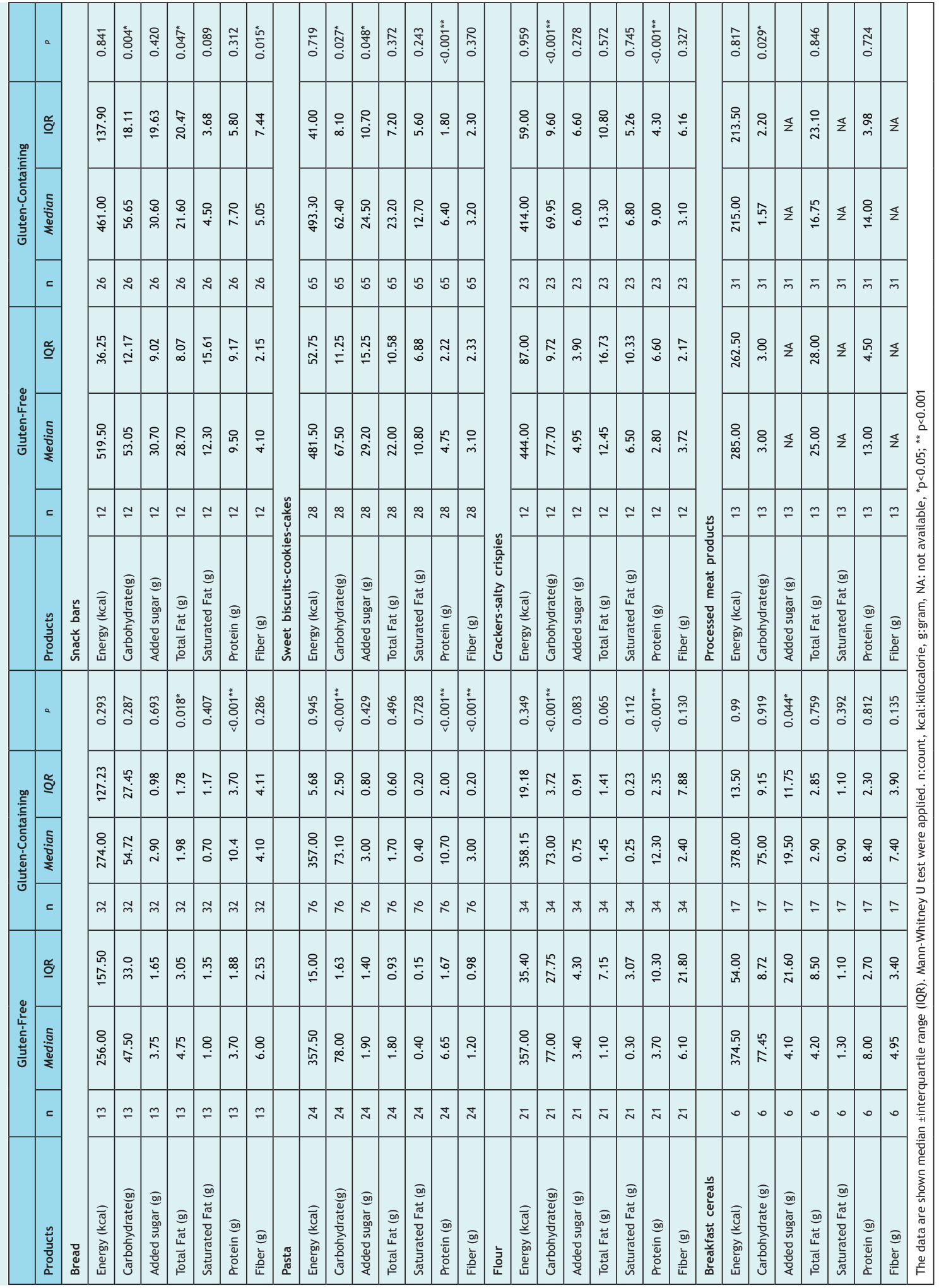


carbohydrate value was $77.70 \mathrm{~g}$ in gluten-free products and $69.95 \mathrm{~g}$ in gluten-containing products $(p<0.001)$. When the median amount of protein in gluten-free products was $2.80 \mathrm{~g}$, it was found to be $9.00 \mathrm{~g}$ in gluten-containing products $(p<0.001)$. As the crackerssalty crispies group was examined, no statistically significant difference was found between the groups in terms of energy, added sugar, total fat, saturated fat, and dietary fiber $(p>0.05)$.

The comparison of the prices of gluten-free and gluten-containing products examined in terms of energy and macro-nutrients is given in (Figure 1). The price assessments are compared in terms of the Turkish liras (Tls) value paid per $100 \mathrm{~g}$ of the product. In the bread group, the median value of gluten-free products was $8.84 \mathrm{Tls}$, whereas it was $1.37 \mathrm{Tls}$ for glutencontaining products $(p<0.001)$. In the pasta group, the median value was $4.36 \mathrm{Tls}$ for gluten-free products and $0.38 \mathrm{Tls}$ for gluten-containing products $(p<0.001)$. While the median value of gluten-free products was 2.66 Tls in flour group products, it was 0.49 Tls in glutencontaining products $(p<0.001)$. The median value of breakfast cereals was 12.96 in gluten-free products, while it was $2.36 \mathrm{Tls}$ in gluten-containing products $(p<0.001)$. In the processed meat products group, the median value for gluten-free products was $6.18 \mathrm{Tls}$, whereas, for gluten-containing products, it was $5.78 \mathrm{Tls}$ $(p>0.05)$. In the snack bar group, the median value of gluten-free products was $9.87 \mathrm{Tl}$, whereas it was 6.42 Tls for gluten-containing products $(p<0.001)$. When the biscuit-cookie-cake group products were examined, it was found that while gluten-free products were 14.31 Tls, it was $1.63 \mathrm{Tls}$ for gluten-containing products $(p<0.001)$. In the cracker-salted crispies, gluten-free products were 15.30 Tls while it was 1.28 Tls for glutencontaining products $(p<0.001)$.

\section{DISCUSSION and CONCLUSION}

In this research, a total of 433 products, 129 gluten-free products, and 304 gluten-containing products were included. Gluten-free products, which have become popular with the development of food processing techniques, attract attention with their increasing consumption, especially in a healthy population (17). There is a perception and opinion that gluten-free products are healthy. While highlighting the organoleptic properties of gluten-free products, nutritional values can be ignored. However, the long-term effects of gluten-free diet, carbohydrate, protein, B-group vitamins, dietary fiber, and iron are found to be inadequate nutrients (18).

Grains and grain products are one of the dietary sources that provide energy, carbohydrate, protein, dietary fiber, and B-group vitamins. In the gluten-free diet, the replacement of grain products removed from the individual's consumption is recommended. The low fiber content in gluten-free products is another critical issue encountered in the gluten-free diet. In recent studies, adequate intake of dietary fiber is vital in many areas, from the development of chronic diseases to bowel health (19). In this study, the gluten-free pasta group has less dietary fiber than gluten-containing pasta group $(p<0.001)$. Similar to this study, Jamieson et al., found that pasta groups have less dietary fiber than gluten-containing counterparts (20). However, a study conducted in Austria also found that gluten-free pasta contains more dietary fiber than equivalent products (21). These results may be due to different product types and enrichment processes in countries. Because gluten-free products are not enriched with dietary fiber in Turkey. In this study, dietary fiber content of the majority of product groups (except for pasta and snack bars) was found to be similar. The gluten-free snack bars had less dietary fiber than gluten-containing snack bars. Unlike a study conducted in Canada was found that gluten-free bars were higher in fiber than gluten-containing bars (20). In this study, gluten-free foods in bread, pasta, and flour products were found to contain less protein than gluten-containing counter products $(p<0.001)$. Similar to this study, in Canada and Spain, GF breads have less protein and more total fat than $\mathrm{GC}$ equivalents $(22,23)$. The reason for the low protein content of gluten-free products is thought to be the removal of gluten, which is the primary protein in wheat flour from these products. 
Allen and Orfila (2018) were found similar energy and saturated fat between standard breads and GF breads in the UK (2). In the present study, the energy and saturated fat contents of gluten-free breads were found to be similar to gluten-containing counterparts, but they contained more total fat $(p<0.05)$. In addition, gluten-free bread contains less protein $(p<0.001)$. On the other hand, carbohydrate, added sugar, and fiber contents of gluten-free breads were similar.

Breakfast cereals are an essential alternative for the first meal of the day. A study in Australia found that gluten-free breakfast cereals contain lower dietary fiber than gluten-containing alternatives (7). Similarly, the dietary fiber content of gluten-free breakfast cereals was found to be low in this study, but it was not statistically significant. Gluten-free breakfast cereals were found to contain less added sugar than their counterparts $(p<0.05)$. Breakfast cereals can help prevent vitamin and mineral deficiencies through enrichment (24). The consumption of gluten-free breakfast cereals in gluten-free diet may be one of the right steps to prevent long term vitamin and mineral deficiencies.

Simple sugars increase the consumption of packaged products by creating a sweet taste (25). However, studies suggest that simple sugar consumption should be reduced in the diet. World Health Organization recommends that the amount of simple sugar to be taken by diet should not exceed $10 \%$ of the total energy per day (26). In daily intake, the contribution of packaged products to simple sugar intake is enormous. Therefore, it is recommended to limit the consumption of packaged foods. Similarly, high gluten-free packaged products contain simple sugar. In sweet biscuits-cakes-cookies group, glutenfree products contain higher sugar than their glutencontaining counterparts $(p<0.05)$. However, a study in Austria showed no difference in the amount of added sugar in gluten-free foods (21).

The total amount of fat consumed in the diet is another essential nutrient that needs to be reduced.
Increased consumption of processed, packaged products increased the total amount of fat and saturated fatty acids consumed in the diet. The risk of heart disease increases with the increase in total fat and saturated fatty acids consumed in the diet (27). In a study, gluten-free cereal/granola bars were found to contain higher total fat than their glutencontaining counterparts (20). In this study, gluten-free snack bars were found to contain higher fat than their counterparts $(p<0.05)$.

The availability and price of gluten-free products produced for particular groups are one of the crucial topics for the consumer. Accessibility is not covered in this study. As mentioned above, the contents of gluten-free products differ from their glutencontaining counterparts. While gluten-free products in different food groups had less protein and less fiber content, high fat, high saturated fatty acids, and high sugar content were determined. In this study was found that the gluten-free products groups except for processed meat products were more expensive than gluten-containing product groups $(p<0.001)$. The studies conducted in different countries were also found that the price of gluten-free products was higher compare to gluten-containing products $(14,21$, $28,29)$. The high price of gluten-free products can be a problem for patients with celiac disease. It would be useful to carry out projects to reduce the price of these products. In Turkey, a monthly support fee for individuals who need to use gluten-free products are made. However, this financial support is provided according to the age of the patient, and most of the time, this financial support does not cover any of these products.

The sample of this study consisted of 304 products in the gluten-containing group and 129 products in the gluten-free group. Additionally, the products were divided into eight subgroups. As far as we know, this is the first study conducted in Turkey regarding the price and the variety of gluten-free products. As the study is carried out on the largest supermarkets 
in Ankara, there is a variety of products compared to other parts of the country. The number of products included in the study could be further increased. This situation is one of the limitations of the present study. Another limitation of the study is the unavailability to compare micronutrient contents between the glutenfree group and the gluten-containing group because there was limited data about micronutrients in the label of the products. This study was done in only one city of Turkey (Ankara), so the study does not present enough information about the availability of glutenfree products in general of the country. Future studies should be planned to cover the whole country for general information.
In conclusion, it is not the right approach to recommend gluten-free products to healthy individuals. Despite the variations of food groups, gluten-free products are not nutritionally superior for healthy people because of their high carbohydrate, high total fat, low protein, and low dietary fiber contents. However, the high prices of the products should also be considered. So that gluten-free products should not be recommended for healthy individuals. The gluten-free diet should be prepared by a dietician who is experts in gluten-related disease field under the needs of the individual and to reduce the consumption of packaged products.

\section{ACKNOWLEDGMENTS}

The authors would like to thank them for their contributions in the data collection process, dietician Sidıka Merve Cansever, dietician Ümmügülsüm Azili, dietician Gülșah Altingoz and dietician Gizem Emer.

\section{ETHICS COMITTEE APPROVAL}

* This study does not require Ethics Committee Approval.

\section{CONFLICT OF INTEREST}

The authors declare no conflict of interest.

\section{REFERENCES}

1. Drewnowski A, Popkin BM. The nutrition transition: new trends in the global diet. Nutr Rev. $1997 ; 55(2): 31-43$.

2. Allen B, Orfila C. The Availability and Nutritional Adequacy of Gluten-Free Bread and Pasta. Nutrients. 2018;10 (10):1370.

3. Gaesser GA, Angadi SS. Gluten-free diet: imprudent dietary advice for the general population? J Acad Nutr Diet. 2012;112(9):1330-3.
4. Armstrong MJ, Hegade VS, Robins G. Advances in coeliac disease. Curr Opin Gastroenterol. 2012;28(2):104-12.

5. Reilly NR. The gluten-free diet: Recognizing fact, fiction, and fad. J Pediatr. 2016;175:206-10.

6. Rostami K, Bold J, Parr A, Johnson MW. Glutenfree diet indications, safety, quality, labels, and challenges. Nutrients. 2017;9 (8):846. 
7. Wu JH, Neal B, Trevena H, Crino M, Stuart-Smith W, Faulkner-Hogg K, et al. Are gluten-free foods healthier than non-gluten-free foods? An evaluation of supermarket products in Australia. $\mathrm{Br} \mathrm{J}$ Nutr. 2015;114(3):448-54.

8. Jones AL. The gluten-free diet: Fad or necessity? Diabetes Spectr. 2017;30(2):118-23.

9. Theethira TG, Dennis M. Celiac disease and the gluten-free diet: Consequences and recommendations for improvement. Dig Dis. 2015;33(2):175-82.

10. Vici G, Belli L, Biondi M, Polzonetti V. Gluten free diet and nutrient deficiencies: A review. Clin Nutr. 2016;35(6):1236-41.

11. Niland B, Cash BD. Health benefits and adverse effects of a gluten-free diet in non-Celiac disease patients. Gastroenterol Hepatol. 2018;14(2):82-91.

12. Pantaleão LC, Rogero MM, Amancio OMS. Brazilian Society for Food and Nutrition position statement: Gluten-free diet. Nutrire. 2016;41(1).

13. Singh J, Whelan K. Limited availability and higher cost of gluten-free foods. J Hum Nutr Diet. 2011;24(5):479-86.

14. Burden M, Mooney PD, Blanshard RJ, White WL, Cambray-Deakin DR, Sanders DS. Cost and availability of gluten-free food in the UK: in store and online. Postgrad Med J. 2015;91(1081):622-6.

15. Marcason W. Is there evidence to support the claim that a gluten-free diet should be used for weight loss? J Am Diet Assoc. 2011;111(11):1786.

16. Guzel S, Keser A, Hatun S. Investigating the nutritional value of foods targeting children. Eat Weight Disord. 2020;25(1):51-8.

17. Hüttner EK, Arendt EK. Recent advances in glutenfree baking and the current status of oats. Trends in Food Science and Technology. 2010;21(6):303-12.

18. Theethira TG, Dennis M, Leffler DA. Nutritional consequences of Celiac disease and the glutenfree diet. Expert Rev Gastroenterol Hepatol. 2014;8(2):123-9.

19. Slavin JL. Position of the American Dietetic Association: Health implications of dietary fiber. J Am Diet Assoc. 2008;108(10):1716-31.
20. Jamieson JA, Weir M, Gougeon L. Canadian packaged gluten-free foods are less nutritious than their regular gluten-containing counterparts. PeerJ. 2018;6:e5875.

21. Missbach B, Schwingshackl L, Billmann A, Mystek A, Hickelsberger M, Bauer G, et al. Gluten-free food database: the nutritional quality and cost of packaged gluten-free foods. PeerJ. 2015;3:e1337.

22. Kulai T, Rashid M. Assessment of nutritional adequacy of packaged gluten-free food products. Can J Diet Pract Res. 2014;75(4):186-90.

23. Miranda J, Lasa A, Bustamante MA, Churruca I, Simon E. Nutritional differences between a glutenfree diet and a diet containing equivalent products with gluten. Plant Foods Hum Nutr. 2014;69(2):1827.

24. Fulgoni VL, Buckley RB. The Contribution of fortified ready-to-eat cereal to vitamin and mineral intake in the U.S. population, NHANES 2007-2010. Nutrients. 2015;7(6):3949-58.

25. Ismail Al, Tanzer JM, Dingle JL. Current trends of sugar consumption in developing societies. Community Dent Oral Epidemiol. 1997;25(6):43843.

26. World Health Organization (WHO). Diet, Nutrition and the Prevention of Chronic Diseases: WHO Technical Report Series 916; 2003 [Available from: https://apps.who.int/iris/bitstream/ handle/10665/42665/WHO_TRS_916.pdf;jsession id=E964F141EB30BA1594B1EFD241B1BD83?sequen $\mathrm{Ce}=1$. ISSN 012-3054.

27. Food and Agriculture Organization of the United Nations (FAO). Fats and fatty acids in human nutrition Report of an expert consultation. 2008. ISBN 978-92-5-106733-8.

28. Fry L, Madden AM, Fallaize R. An investigation into the nutritional composition and cost of gluten-free versus regular food products in the UK. J Hum Nutr Diet. 2018;31(1):108-20.

29. Stevens L, Rashid M. Gluten-free and regular foods: a cost comparison. Can J Diet Pract Res. 2008;69(3):147-50. 